\title{
Comparison of Growth and Yield Characteristics of Mid-Season Hybrid Rice under Different Yield Levels
}

\author{
Xiaolong Zhong ${ }^{1}$, Bingbing Zhao ${ }^{1}$, Manyu Huang ${ }^{1}$, Hafiz Athar Hussain ${ }^{2, *}$ (D), \\ Saddam Hussain ${ }^{3}$ (D) Linjun Cai ${ }^{1}$, Han Yun ${ }^{1}$, Guanghua $\mathrm{He}^{1}$ and Changwei Zhang ${ }^{1, *}$ \\ 1 Rice Research Institute, Chongqing Key Laboratory of Application and Safety Control of Genetically \\ Modified Crops, Academy of Agricultural Sciences, Southwest University, Chongqing 400715, China; \\ ZhongXL2019@163.com (X.Z.); zbb20200811@163.com (B.Z.); huangmanyu0710@163.com (M.H.); \\ 18308462842@163.com (L.C.); 15225371326@163.com (H.Y.); heghswu@163.com (G.H.) \\ 2 Institute of Environment and Sustainable Development in Agriculture, Chinese Academy of \\ Agricultural Sciences, Beijing 100081, China \\ 3 Department of Agronomy, University of Agriculture, Faisalabad 38040, Pakistan; \\ sadamhussainuaf@gmail.com \\ * Correspondence: atharhussainswu@yahoo.com (H.A.H.); zcw2013@swu.edu.cn (C.Z.); \\ Tel.: +86-023-6825-0158 (C.Z.); Fax: +86-023-6825-1264 (C.Z.)
}

Received: 22 September 2020; Accepted: 23 November 2020; Published: 27 November 2020

\begin{abstract}
Analysis of growth and yield characteristics of rice with different yield levels is very important for the breeding of high-yield rice cultivators. To investigate the yield components' variation, morphological characteristics of the panicles, leaves, and stems of rice varieties under different yield levels, a two-year field experiment was conducted in Chongqing China. The 20 mid-season Indica hybrid rice varieties were classified into three groups based on yield, comprising high-yield group (HG), mid-yield group (MG), and low-yield group (LG). The main reason for the superior yield of HG is that the varieties of this group had a significantly higher number of effective panicles per unit area than the MG and LG. In plant type factors, the leaf type factors were the most important reason causing yield difference of HG, MG, and LG. The average leaf roll index, average leaf length to width ratio, average leaf base angle, average leaf droop angle, and average leaf pillow distance of the upper three leaves were significantly or significantly negatively correlated with the yield, while the average leaf width, average leaf area, and the average distance of leaf edge were significantly or significantly positively correlated with yield, and the leaf droop angle was the most important plant type factor affecting the yield. Based on these results, we further quantified the plant type factors of HG and constructed an ideal plant type model for high-yield hybrid mid-season rice. Theoretical and practical basis could be provided for breeding mid-season Indica hybrid rice with super-high yield in the future to ensure food security.
\end{abstract}

Keywords: hybrid rice; high-yield varieties; plant-type characteristics; effective panicles; leaf droop angle

\section{Introduction}

Rice (Oryza sativa) is one of the most important food crops in the world, with about $50 \%$ of the world's population living on rice [1]. Meanwhile rice provides $35 \%-60 \%$ of the dietary calories consumed by three billion people [2]. With the continuing increase in population, there is an urgent need to improve rice yield. However, with the acceleration of urbanization, much of the available farmland is being gradually transformed into land for urban infrastructure [3]. Without being able to increase the planting area, it is very difficult to increase rice yield, and this conundrum is particularly 
evident in most of the traditional rice-producing countries in the world. The cultivation of salt-tolerant rice cultivar (sea rice) has expanded part of the planting area of rice, but it is still not enough to fully meet the food demand of the world population [4]. In order to increase rice production, it is necessary to increase the yield per unit area. Therefore, the characteristics of high-yield rice have been the focus of several rice breeders and cultivators for some time.

An ideal structure of panicle is the physiological basis for ensuring large sink capacity of plants [5], and an ideal leaf-type structure can improve the photosynthesis of a population through comprehensive improvement of its structure and light conditions, creating the potential for high yield [6], while an ideal stem structure can not only improve the lodging resistance but also promote the smooth transportation of photosynthate of plants [7]. These ideal plant type characteristics can ensure a high yield of rice in different directions. The yield of rice consists of four components: effective number of panicles per unit area, number of spikelets per panicle, seed setting rate, and filled grain weight [8]. At present, the viewpoint of increasing rice yield by expanding sink capacity has been gradually recognized by many domestic and overseas scholars [9]. Breeders have further expanded the sink capacity of rice based on the improvement of the yield components of rice after many years of research and have bred high-yielding varieties, thus further improving rice yield. There are three ways to expand sink capacity: increasing spikelets per panicle, increasing spikelets per panicle or grain weight, or both, and increasing the effective number of panicles per unit area [10]. The high-yielding varieties bred on the basis of these methods have achieved a rise in rice yield in actual production.

After further expanding the sink capacity of rice, how to improve the supply and transport capacity of photosynthate is an urgent problem for breeders and cultivators. Researches on high-yield rice have tended to focus on traditional physiological research for a long time, but the concept of an 'ideal' plant type provided a new avenue of research for further improving rice yield [11]. An ideal plant type refers to the combination of various beneficial traits related to high yield under specific ecological and productive conditions [12]. It consists of three parts: ideal panicle type, ideal leaf type, and ideal stem type. Over the years, researchers have studied the plant types of high-yield rice from the perspectives of plant spatial configuration [10], soil climate [13], and cultivation measures [14], and have provided a number of key advances in our understanding of this topic. Further comparison of plant-type characteristics of rice varieties under different yield levels will help us understand the relationship between plant-type characteristics and yield of recently bred varieties, which will be a guide for cultivation of high-yield rice varieties in the future.

Field experiments were conducted in Chongqing China in 2017 and 2018, using newly bred mid-season late-maturing indica hybrid rice varieties. The main aims of the study are (1) to reveal the variations in plant-type characteristics of indica hybrid rice for different levels of yield, (2) to determine the plant-type factors that have significant effects on yield and to establish plant-type models of high-yield varieties, and (3) to provide a theoretical and practical basis for the improvement of plant type of hybrid rice in the future.

\section{Materials and Methods}

\subsection{Plant Materials and Experimental Design}

In this study, 20 varieties of hybrid mid-season rice approved within 10 years were tested, which met the requirements of national and provincial (municipal) testing in the upper reaches of the Yangtze River of China and have been popularized as excellent indica hybrid rice varieties. Among these, 11 varieties (Longliangyou1206, Shenliangyou5814, Yuxiang203, Yixiang2115, Yixiangyou1108, Nei6you138, Leyou918, Nei-5-you907, Chuanyou8377, Nei-6-you1116, and Jingyouhuazhen) passed the national certification of crop varieties for the upper reaches of the Yangtze River. Six varieties (Dxiang101, Luxiangyou177, Chuanxiangyou308, Jiayou968, Qianxiangyou677, and Yixiangyou2905) passed the certification of crop varieties for Sichuan Province, and three varieties (Y-Liangyou35, Zhongyou596, and Xida-5-You727) passed the certification of crop varieties for Chongqing Municipal 
(Table 1). The experiment was devised using single-factor random block design with three replications. Each plot was $5.3 \mathrm{~m}$ long and $2 \mathrm{~m}$ wide, with 20 rows and 10 holes per row, and 1 plant per hole.

Table 1. Approval state, approval year, and main planting areas of 20 tested varieties.

\begin{tabular}{|c|c|c|c|}
\hline Variety & Approval State & Approval Year & Main Planting Areas \\
\hline Longliangyou1206 & National approval of China & 2016 & $\begin{array}{l}\text { Yunnan province, Guizhou province, } \\
\text { Chongqing municipality, etc. }\end{array}$ \\
\hline Shenliangyou 5814 & National approval of China & 2017 & $\begin{array}{l}\text { Sichuan province, Guizhou province, } \\
\text { Yunnan province, etc. }\end{array}$ \\
\hline Y-liangyou35 & Chongqing Municipality approval of China & 2015 & Chongqing municipality, etc. \\
\hline Yuxiang203 & National approval of China & 2010 & $\begin{array}{l}\text { Guizhou province, Chongqing } \\
\text { municipality, Sichuan province, etc. }\end{array}$ \\
\hline Yixiang2115 & National approval of China & 2012 & $\begin{array}{l}\text { Yunnan province, Guizhou province, } \\
\text { Chongqing municipality. etc. }\end{array}$ \\
\hline Yixiangyou1108 & National approval of China & 2014 & $\begin{array}{l}\text { Yunnan province, Guizhou province, } \\
\text { Chongqing municipality, etc. }\end{array}$ \\
\hline Nei-6-you138 & National approval of China & 2016 & $\begin{array}{l}\text { Sichuan province, Yunnan province, } \\
\text { Guizhou Province, etc. }\end{array}$ \\
\hline D-xiang101 & Sichuan Province approval of China & 2014 & Sichuan province, etc. \\
\hline Leyou918 & National approval of China & 2014 & $\begin{array}{l}\text { Yunnan province, Guizhou province, } \\
\text { Sichuan province, etc. }\end{array}$ \\
\hline Nei-5-you907 & National approval of China & 2016 & $\begin{array}{l}\text { Yunnan province, Guizhou province, } \\
\text { Sichuan province, etc. }\end{array}$ \\
\hline Luxiangyou177 & Sichuan Province approval of China & 2014 & Sichuan province, etc. \\
\hline Chuanxiangyou 308 & Sichuan Province approval of China & 2013 & Sichuan province, etc. \\
\hline Jiayou968 & Sichuan Province approval of China & 2015 & Sichuan province, etc. \\
\hline Zhongyou596 & Chongqing Municipality approval of China & 2013 & Chongqing municipality, etc. \\
\hline Qianxiangyou677 & Sichuan Province approval of China & 2017 & Sichuan province, etc. \\
\hline Chuanyou8377 & National approval of China & 2012 & $\begin{array}{l}\text { Guizhou province, Chongqing } \\
\text { municipality, Sichuan province, etc. }\end{array}$ \\
\hline Nei-6-you1116 & National approval of China & 2017 & $\begin{array}{c}\text { Sichuan province, Guizhou province, } \\
\text { Yunnan province, etc. }\end{array}$ \\
\hline Jingyouhuazhen & National approval of China & 2017 & $\begin{array}{l}\text { Sichuan province, Guizhou province, } \\
\text { Yunnan province, etc. }\end{array}$ \\
\hline Yixiangyou2905 & Sichuan Province approval of China & 2015 & Sichuan province, etc. \\
\hline Xida-5-you727 & Chongqing Municipality approval of China & 2017 & Chongqing municipality, etc. \\
\hline
\end{tabular}

National approval of China indicates that the rice variety meet the requirements of national testing of crop variety in the upper reaches of the Yangtze River of China. Sichuan Province approval of China indicates that the rice variety meet the requirements of Sichuan Province testing of crop variety. Chongqing Municipality approval of China indicates that the rice variety meet the requirements of Chongqing Municipality testing of crop variety.

\subsection{Experimental Site and Field Management}

The experiments were conducted in 2017 and 2018 at the rice experimental field station of the Xiema Test Base of the Rice Research Institute of Southwest University at Chongqing $\left(29^{\circ} 45^{\prime} 26^{\prime \prime} \mathrm{N}\right.$, $106^{\circ} 23^{\prime} 2^{\prime \prime} \mathrm{E}, 255 \mathrm{~m}$ altitude), China. The tillage layer $\mathrm{pH}$ was 7.07 , and contained $31.2 \mathrm{~g} \mathrm{~kg}^{-1}$ organic matter, $127 \mathrm{mg} \mathrm{kg}^{-1}$ alkali-hydrolyzed nitrogen, $18.7 \mathrm{mg} \mathrm{kg}^{-1}$ available phosphorus, and $93.5 \mathrm{mg} \mathrm{kg}^{-1}$ available potassium. The growth period of the tested cultivars was 150-156 days. Seeds of the cultivars were sown on 12 March, transplanted on 15 April, headed from 1 to 6 July, and matured and harvested from 10 to 16 August. The total amount of nitrogen fertilizer applied (urea, containing $46.4 \% \mathrm{~N}$ ) was $0.24 \mathrm{t} \mathrm{hm}^{-2}$. The amounts of base fertilizer, tiller fertilizer, and panicle fertilizer accounted for $40 \%, 20 \%$, and $40 \%$ of the total nitrogen application, respectively. The amount of phosphate fertilizer $\left(\mathrm{P}_{2} \mathrm{O}_{5}\right)$ was $0.12 \mathrm{t} \mathrm{hm}^{-2}$ and potassium fertilizer $\left(\mathrm{K}_{2} \mathrm{O}\right)$ was $0.24 \mathrm{t} \mathrm{hm}^{-2}$, which were applied as base fertilizers. Pests and diseases were controlled in accordance with local high-yield cultivation management practices.

\subsection{Meteorological Conditions}

The meteorological conditions of the experimental site for the two years are shown in Figure 1. 

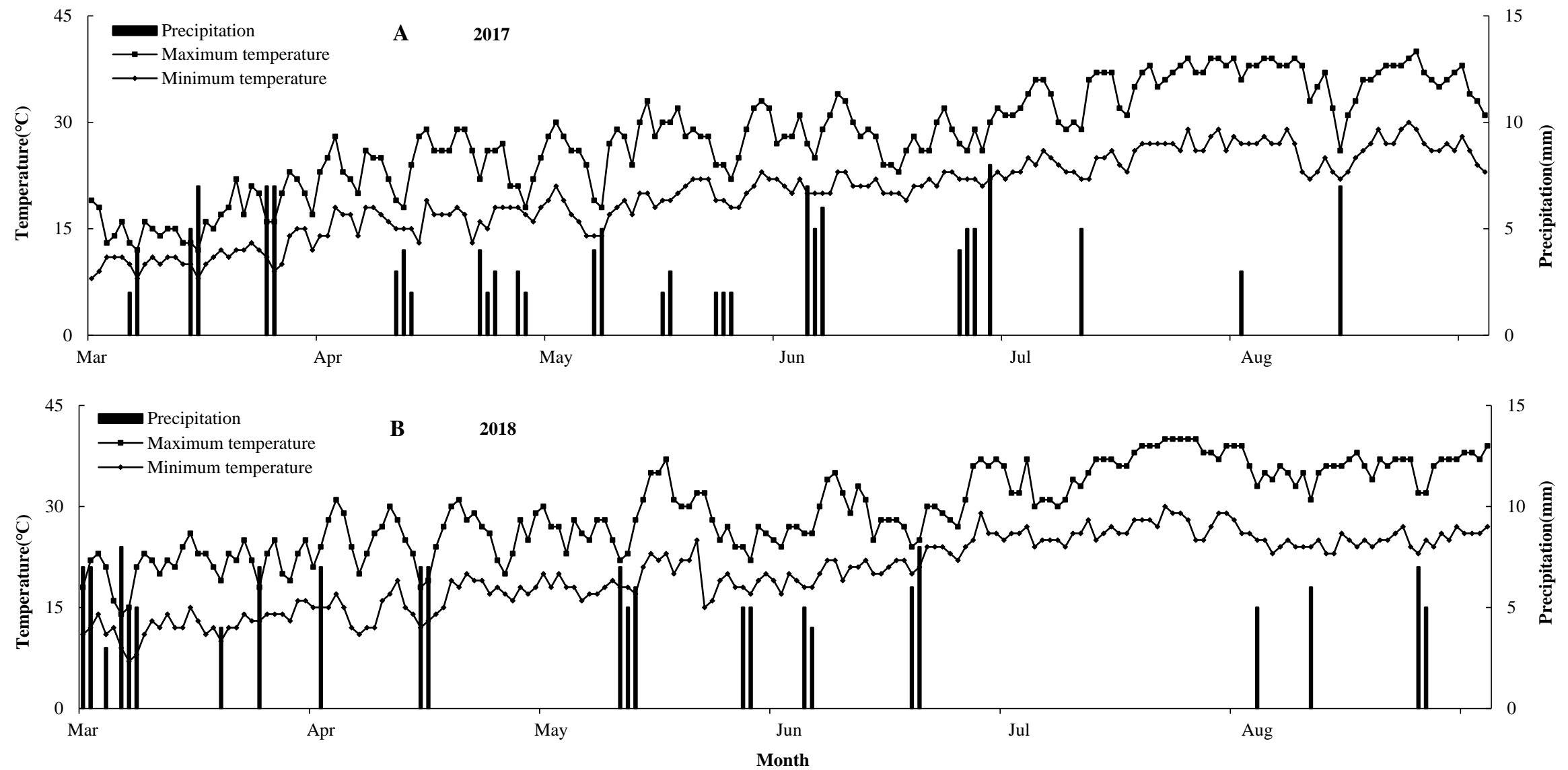

Figure 1. The meteorological conditions of the experimental site in 2017 and 2018. (A) The meteorological conditions of the experimental site in 2017 and (B) the meteorological conditions of the experimental site in 2018. 


\subsection{Sampling and Measurements}

At the full heading stage, five representative holes of the rice main stem were selected from each tested rice variety to determine the internode length and width, leaf pillow distance, leaf basal angle, leaf opening angle, leaf length, leaf width, and distance of the leaf edge of the upper three leaves from the main stem. The internode length and width were measured with a ruler and vernier caliper respectively, and the width of the middle internode is regarded as the internode width. Leaf pillow distance, leaf length, leaf width, and distance of the leaf edge were measured with a ruler, and the leaf width was the widest width of leaves. Leaf basal angle and leaf opening angle were measured with a protractor. Particularly, the angle between the leaf vein of the petiole and the stem was defined as the leaf base angle $(\alpha)$, and the angle between leaf tip, petiole, and stem was measured as the leaf opening angle ( $\beta$ ) (Figure 2). The leaf rolling index was calculated according to Hu et al. [15].

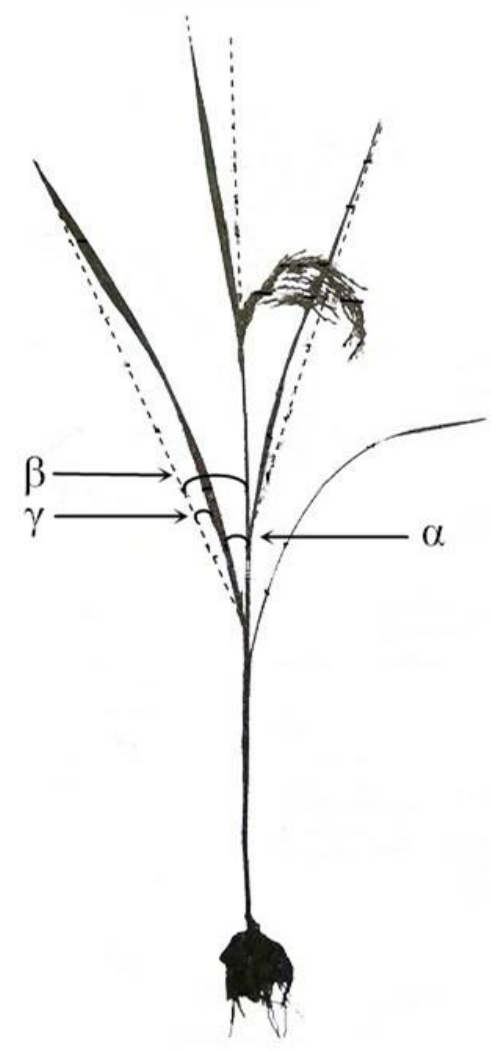

Figure 2. Schematic diagram of leaf posture indexes. $\alpha$ : leaf basal angle, $\beta$ : leaf opening angle, $\gamma$ : leaf droop angle.

At the maturity stage, 30 holes were randomly selected for threshing, drying, and weighing, and moisture content was measured using a TD-6 computer grain moisture meter (Kett Company, Tokyo, Japan). The yield was calculated when the moisture content was $14 \%$. The representative middle plants were divided into 5 holes according to the average number of effective panicles and air-dried to allow measurement of plant height, number of effective panicles, panicle length, number of primary branch, number of second branch, number of spikelets per panicle, 1000-grain weight, and filled grain rate (\%). A ruler was used to measure plant height and panicle length, and the electronic balance (GR-202, A\&D Co., Ltd., Tokyo, Japan) was used to measure 1000-grain weight. Measurements for each variety were repeated three times. The tillering dynamics records were investigated from the 
beginning of tillering, two investigation points were set up in each block, and 10 holes were found for each survey point. The relevant formulas are as follows:

$$
\begin{gathered}
\text { Leaf droop angle }\left({ }^{\circ}\right)=\text { leaf opening angle }(\beta)\left({ }^{\circ}\right)-\text { leaf basal angle }(\alpha)\left(^{\circ}\right) ; \\
\text { Leaf area }\left(\mathrm{cm}^{2}\right)=0.75 \times \text { leaf length }(\mathrm{cm}) \times \text { leaf width }(\mathrm{cm}) ; \\
\text { Leaf rolling index }(\%)=(1-\text { distance of leaf } / \text { leaf width }) \times 100 .
\end{gathered}
$$

\subsection{Statistical Analysis}

Microsoft Excel 2010 (Microsoft, Redmond, WA, USA) was used for data records, and IBM SPSS Statistics 22.0 (IBM Corporation, Armonk, NY, USA) was used for data analysis. The systematic cluster was done using the between-groups linkage method to cluster the tested materials into different yield level types. Analysis of variance (ANOVA) was done using the generalized linear model (GLM) procedure to determine sources of variation, and the least significant difference (LSD) method was used to perform multiple comparisons among different yield level cultivar groups at the 0.05 probability level. The percentages were carried out following square root-arcsine transformation.

\section{Results}

\subsection{Clustering of Varieties under Different Yield Levels}

The total growth period of the tested varieties was 150-156 days, the period from sowing to heading was 111-116 days, and from heading to maturity was 35-44 days. Variance analysis showed that varieties had significant differences in both yearly and two-year average yields (Table 2), indicating that the total growth periods of the tested varieties were similar, and the yield level of the tested

\begin{tabular}{|c|c|c|c|c|c|c|}
\hline \multirow{2}{*}{ Variety } & \multirow{2}{*}{$\begin{array}{l}\text { Days to } \\
\text { Heading } \\
\text { (d) }\end{array}$} & \multirow{2}{*}{$\begin{array}{c}\text { Days of } \\
\text { Heading to } \\
\text { Maturity (d) }\end{array}$} & \multirow{2}{*}{$\begin{array}{l}\text { Days to } \\
\text { Maturity } \\
\text { (d) }\end{array}$} & \multicolumn{3}{|c|}{ Yield (t ha $\left.{ }^{-1}\right)$} \\
\hline & & & & 2017 & 2018 & $\bar{x}$ \\
\hline Longliangyou1206 & 114 & 39 & 153 & 9 cde & 8.89 ghi & $8.95 \mathrm{ef}$ \\
\hline Shenliangyou5814 & 113 & 39 & 152 & 9 cde & 8.84 ghi & $8.92 \mathrm{efg}$ \\
\hline Y-liangyou35 & 112 & 43 & 155 & 8.52 ghi & $8.43 \mathrm{j}$ & $8.48 \mathrm{i}$ \\
\hline Yuxiang203 & 116 & 37 & 153 & $8.63 \mathrm{fgh}$ & $8.68 \mathrm{ij}$ & 8.66 ghi \\
\hline Yixiang2115 & 114 & 41 & 155 & $8.21 \mathrm{i}$ & $8.64 \mathrm{ij}$ & $8.43 \mathrm{i}$ \\
\hline Yixiangyou1108 & 115 & 35 & 150 & $9.28 \mathrm{abcd}$ & $9.71 \mathrm{ab}$ & $9.5 \mathrm{ab}$ \\
\hline Nei-6-you138 & 112 & 41 & 153 & 8.95 def & 9.24 def & 9.1 cde \\
\hline D-xiang101 & 112 & 42 & 154 & $8.81 \mathrm{efg}$ & 8.73 hij & $8.77 \mathrm{fgh}$ \\
\hline Leyou918 & 114 & 42 & 156 & $9.46 \mathrm{ab}$ & $9.58 \mathrm{abc}$ & $9.52 \mathrm{ab}$ \\
\hline Nei-5-you907 & 113 & 42 & 155 & $9.24 \mathrm{abcd}$ & 9.34 cdef & $9.29 \mathrm{bcd}$ \\
\hline Luxiangyou177 & 115 & 40 & 155 & 8.45 hi & $8.61 \mathrm{ij}$ & $8.53 \mathrm{hi}$ \\
\hline Chuanxiangyou308 & 112 & 43 & 155 & 9 cde & 8.88 ghi & 8.94 ef \\
\hline Jiayou968 & 113 & 40 & 153 & 8.78 efgh & $9.08 \mathrm{efg}$ & $8.93 \mathrm{efg}$ \\
\hline Zhongyou596 & 115 & 37 & 152 & 9.05 cde & $9.07 \mathrm{fg}$ & $9.06 \mathrm{de}$ \\
\hline Qianxiangyou677 & 112 & 39 & 151 & 9.09 cde & $9.48 \mathrm{abcd}$ & $9.29 \mathrm{bcd}$ \\
\hline Chuanyou8377 & 116 & 37 & 153 & $9.32 \mathrm{abc}$ & $9.44 \mathrm{abcd}$ & $9.38 \mathrm{ab}$ \\
\hline Nei-6-you1116 & 111 & 44 & 155 & $9.21 \mathrm{abcd}$ & $9.51 \mathrm{abcd}$ & $9.36 \mathrm{abc}$ \\
\hline Jingyouhuazhen & 114 & 39 & 153 & $9.51 \mathrm{a}$ & $9.74 \mathrm{a}$ & $9.63 \mathrm{a}$ \\
\hline Yixiangyou2905 & 113 & 42 & 155 & $9.21 \mathrm{abcd}$ & 9.4 bcde & $9.31 \mathrm{bcd}$ \\
\hline Xida-5-you727 & 114 & 37 & 151 & 9.12 bcde & $9.02 \mathrm{fgh}$ & $9.07 \mathrm{de}$ \\
\hline
\end{tabular}
varieties could be classified.

Table 2. Duration of different stages and yield of 20 rice varieties in 2017 and 2018.

Means followed by a different small letter within a column are significantly different at 0.05 probability levels respectively, as determined by the least significant difference (LSD) method. $\bar{X}$ indicates average yield between 2017 and 2018 of different varieties.

Based on the two-year average yield, 20 varieties were clustered systematically, and the results were divided into three yield-level cultivar groups. The first was the high-yield group (HG) with an average 
yield of $9.41 \mathrm{t} \mathrm{ha}^{-1}$, the second was the mid-yield group (MG) with an average yield of $8.99 \mathrm{t} \mathrm{ha}^{-1}$, and the third was the low-yield group (LG) with an average yield of $8.57 \mathrm{t} \mathrm{ha} \mathrm{h}^{-1}$, and significant differences in yield were noted among the three groups. Among all the varieties, 8 were high-yield, 7 were mid-yield, and 5 varieties were low-yield (Table 3).

Table 3. Clustering results of average yield of different rice varieties from 2017 to 2018.

\begin{tabular}{|c|c|c|c|c|c|c|}
\hline Group & $\begin{array}{l}\text { Average Yield } \\
\left(t \mathrm{ha}^{-1}\right)\end{array}$ & CV (\%) & $\begin{array}{l}\text { Range } \\
\left(\mathrm{t} \mathrm{ha}^{-1}\right)\end{array}$ & \multicolumn{2}{|c|}{ Varieties } & Number \\
\hline HG & $9.41 \mathrm{a}$ & 1.24 & $9.29-9.62$ & $\begin{array}{c}\text { Yixiangyou1108 } \\
\text { Chuanyou8377 } \\
\text { Leyou918 } \\
\text { Nei6you1116 }\end{array}$ & $\begin{array}{c}\text { Nei5you907 } \\
\text { Jingyouhuazhen } \\
\text { Qianxiangyou677 } \\
\text { Yixiangyou2905 }\end{array}$ & 8 \\
\hline MG & $8.99 \mathrm{~b}$ & 0.79 & $8.92-9.10$ & $\begin{array}{c}\text { Longliangyou1206 } \\
\text { Jiayou968 } \\
\text { Shenliangyou5814 } \\
\text { Zhongyou596 }\end{array}$ & $\begin{array}{c}\text { Nei6you138 } \\
\text { Xida5you727 } \\
\text { Chuanxiangyou308 }\end{array}$ & 7 \\
\hline LG & $8.57 \mathrm{c}$ & 1.48 & $8.42-8.77$ & $\begin{array}{l}\text { Yliangyou35 } \\
\text { Luxiangyou177 } \\
\text { Xuxiang203 }\end{array}$ & $\begin{array}{l}\text { Yixiang2115 } \\
\text { Dxiang101 }\end{array}$ & 5 \\
\hline
\end{tabular}

HG, MG, and LG indicate high-yield varieties group, middle-yield varieties group, and low-yield varieties group. Means followed by a different small letter within a column are significantly different at 0.05 probability levels respectively, as determined by LSD. CV indicates coefficient of variation of average yield of varieties between 2017 and 2018 of different groups.

\subsection{Yield Composition of Different Yield-Level Groups}

The yield per plant of HG in 2017 and 2018 was significantly higher than those of MG and LG (Table 4). Comparing yield components, the number of effective panicles per unit area, filled grain rate, and the number of spikelets per panicle of HG, MG, and LG showed a downward trend, while 1000-grain weight showed an upward trend. The number of effective panicles per unit area of HG in 2017 and 2018 were $172.64 \times 10^{4} \mathrm{ha}^{-1}$ and $175.02 \times 10^{4} \mathrm{ha}^{-1}$ respectively, which were significantly higher than MG and LG in the same years. The 1000-grain weight was 26.85 and $27.48 \mathrm{~g}$ respectively, which were significantly lower than LG in the same years, and the filled grain rate was $83.76 \%$ in 2018 , and the difference between HG and LG was significant. Further correlation analysis showed that the yields per plant were extremely significantly positively correlated with the number of effective panicles per unit area, but not significantly correlated with filled grain rate, 1000-grain weight, or the number of spikelets per panicle of 20 varieties in the two-year experiment.

\subsection{Analysis of Tillering Ability and Panicle-Setting Rate of Different Yield-Level Groups}

The tiller number was recorded from beginning of the tillering stage (0 days), and its variation is shown in Figure 3. During the tillering stage, the tiller number of all groups increased gradually at first and then decreased gradually. The rate of HG tillers increases faster, and the period of the gradual increase was longer, while the tiller number of the late-growth reduction was lower than that of MG and LG. The tiller number of HG was significantly higher than LG from the 28th day, and significantly higher than MG and LG from the 56th day in 2017, while it was significantly higher than LG from the 35th day, significantly higher than MG and LG from the 56 days in 2018. The average highest tiller number of HG over two years was $262.48 \times 10^{4} \mathrm{ha}^{-1}$, which was significantly higher than MG and LG, while the average panicle-setting rate was $66.41 \%$, higher than that of MG and LG, but this did not reach a significant level. The analysis showed that the yield was extremely significantly positively correlated with the panicle-setting rate, and the correlation between yield and the highest tiller number did not reach a significant level. 
Table 4. Yield components of different yield varieties groups from 2017 to 2018.

\begin{tabular}{|c|c|c|c|c|c|c|c|c|c|c|c|}
\hline \multirow{2}{*}{ Group } & \multirow{2}{*}{ Varieties } & \multicolumn{2}{|c|}{ Filled Grain Rate (\%) } & \multicolumn{2}{|c|}{ 1000-Grain Weight (g) } & \multicolumn{2}{|c|}{ Effective Panicles $\left(\times 10^{4} \mathrm{ha}^{-1}\right)$} & \multicolumn{2}{|c|}{ Spikelets (number panicle ${ }^{-1}$ ) } & \multicolumn{2}{|c|}{ Yield (g plant ${ }^{-1}$ ) } \\
\hline & & 2017 & 2018 & 2017 & 2018 & 2017 & 2018 & 2017 & 2018 & 2017 & 2018 \\
\hline \multirow{10}{*}{ HG } & Yixiangyou1108 & 80.23 & 83.59 & 26.44 & 27.55 & 165.32 & 174.68 & 299.00 & 250.01 & 49.66 & 51.59 \\
\hline & Leyou918 & 82.44 & 83.97 & 27.69 & 28.09 & 168.24 & 180.51 & 272.50 & 247.86 & 51.12 & 50.42 \\
\hline & Nei-5-you907 & 80.15 & 84.66 & 26.43 & 28.29 & 173.45 & 171.55 & 247.87 & 252.23 & 52.69 & 46.39 \\
\hline & Qianxiangyou677 & 81.33 & 81.43 & 26.46 & 26.77 & 179.33 & 176.92 & 283.5 & 295.46 & 48.55 & 50.52 \\
\hline & Chuanyou8377 & 84.64 & 83.17 & 28.24 & 27.02 & 162.57 & 156.18 & 248.68 & 264.77 & 50.47 & 49.62 \\
\hline & Nei-6-you1116 & 89.35 & 90.27 & 28.33 & 26.43 & 199.45 & 205.55 & 201.26 & 238.94 & 51.32 & 48.48 \\
\hline & Jingyouhuazhen & 83.46 & 78.37 & 24.67 & 26.67 & 172.36 & 176.39 & 251.21 & 281.06 & 49.69 & 52.95 \\
\hline & Yixiangyou2905 & 86.43 & 84.63 & 26.53 & 28.94 & 160.36 & 158.39 & 241.19 & 251.09 & 50.36 & 48.88 \\
\hline & $\bar{x}$ & $83.5 \mathrm{a}$ & $83.76 \mathrm{a}$ & $26.85 \mathrm{~b}$ & $27.48 \mathrm{~b}$ & $172.64 \mathrm{a}$ & $175.02 \mathrm{a}$ & $255.65 \mathrm{a}$ & 260.18 a & $50.48 \mathrm{a}$ & $49.86 \mathrm{a}$ \\
\hline & SD & 3.2 & 3.36 & 0.93 & 1.13 & 12.48 & 15.17 & 29.84 & 19.10 & 1.26 & 2.01 \\
\hline \multirow{9}{*}{ MG } & Longliangyou1206 & 83.21 & 82.67 & 27.66 & 27.48 & 160.36 & 159.33 & 228.61 & 215.86 & 48.23 & 47.21 \\
\hline & Shenliangyou5814 & 80.12 & 81.46 & 27.98 & 26.88 & 175.35 & 162.15 & 225.11 & 253.88 & 47.21 & 47.92 \\
\hline & Nei-6-you138 & 80.29 & 83.39 & 27.99 & 29.64 & 166.58 & 165.92 & 236.22 & 234.25 & 49.35 & 47.69 \\
\hline & Chuanxiangyou308 & 83.46 & 77.9 & 27.55 & 26.48 & 148.36 & 152.89 & 280.69 & 277.83 & 48.32 & 47.04 \\
\hline & Jiayou968 & 82.45 & 79.51 & 27.13 & 27.89 & 154.39 & 150.61 & 225.15 & 264.95 & 46.52 & 48.73 \\
\hline & Zhongyou596 & 84.65 & 80.61 & 29.24 & 28.36 & 157.68 & 152.32 & 254.8 & 279.08 & 49.32 & 47.28 \\
\hline & Xida-5-you727 & 76.69 & 80.31 & 28.56 & 29.43 & 166.37 & 171.13 & 253.45 & 253.75 & 47.69 & 49.05 \\
\hline & $\bar{x}$ & $81.55 \mathrm{a}$ & $80.83 \mathrm{ab}$ & $28.01 \mathrm{ab}$ & $28.02 \mathrm{ab}$ & $161.3 \mathrm{~b}$ & $159.19 \mathrm{~b}$ & 243.43 a & $254.22 \mathrm{a}$ & $48.09 \mathrm{~b}$ & $47.85 \mathrm{~b}$ \\
\hline & SD & 2.71 & 1.87 & 0.69 & 1.21 & 7.36 & 8.57 & 20.65 & 22.95 & 1.05 & 0.78 \\
\hline \multirow{7}{*}{ LG } & Y-liangyou35 & 81.56 & 82.16 & 28.64 & 27.59 & 146.67 & 143.96 & 258.18 & 248.61 & 44.67 & 45.72 \\
\hline & Yuxiang203 & 83.46 & 76.25 & 28.32 & 30.66 & 158.67 & 152.58 & 215.24 & 259.12 & 45.69 & 46.64 \\
\hline & Yixiang2115 & 79.68 & 82.1 & 28.79 & 30.15 & 156.35 & 152.4 & 238.03 & 216.92 & 46.23 & 43.59 \\
\hline & D-xiang101 & 83.46 & 75.69 & 27.67 & 29.08 & 142.35 & 148.9 & 238.69 & 251.16 & 45.58 & 47.96 \\
\hline & Luxiangyou177 & 75.69 & 75.76 & 27.64 & 28.48 & 144.78 & 143.97 & 265.99 & 253.8 & 43.59 & 47.44 \\
\hline & $\bar{x}$ & 80.77 a & $78.39 \mathrm{~b}$ & $28.21 \mathrm{a}$ & $29.19 \mathrm{a}$ & $149.76 \mathrm{~b}$ & $148.36 \mathrm{~b}$ & $243.22 \mathrm{a}$ & $245.92 \mathrm{a}$ & $45.15 \mathrm{c}$ & $46.27 \mathrm{~b}$ \\
\hline & SD & 3.24 & 3.42 & 0.53 & 1.24 & 7.28 & 4.27 & 19.82 & 16.67 & 1.04 & 1.72 \\
\hline \multicolumn{12}{|c|}{ Analysis of variance } \\
\hline & Year & \multicolumn{2}{|c|}{0.96 NS } & \multicolumn{2}{|c|}{$0.79 \mathrm{NS}$} & \multicolumn{2}{|c|}{$0.01 \mathrm{NS}$} & \multicolumn{2}{|c|}{$0.67^{\mathrm{NS}}$} & \multicolumn{2}{|c|}{$0.03^{\mathrm{NS}}$} \\
\hline & Group & \multicolumn{2}{|c|}{$6.03 * *$} & \multicolumn{2}{|c|}{7.67 ** } & \multicolumn{2}{|c|}{$17.78^{* *}$} & \multicolumn{2}{|c|}{$1.22 \mathrm{NS}$} & \multicolumn{2}{|c|}{$32.23 * *$} \\
\hline & Year $\times$ Group & \multicolumn{2}{|c|}{$0.60^{N S}$} & \multicolumn{2}{|c|}{$1.05^{\mathrm{NS}}$} & \multicolumn{2}{|c|}{$0.11^{\mathrm{NS}}$} & \multicolumn{2}{|c|}{$0.11^{\mathrm{NS}}$} & \multicolumn{2}{|c|}{$1.26^{\mathrm{NS}}$} \\
\hline
\end{tabular}

HG, MG, and LG indicate high-yield varieties group, middle-yield varieties group, and low-yield varieties group. Means followed by a different small letter within a column are significantly different at 0.05 probability levels respectively, as determined by LSD. ** values within the column are significantly different at the 0.01 probability level. NS means not significant at $p=0.05 . \bar{X}$ indicates the average value of indexes of different groups in 2017 and 2018. SD indicates standard deviation of indexes of different groups in 2017 and 2018. 

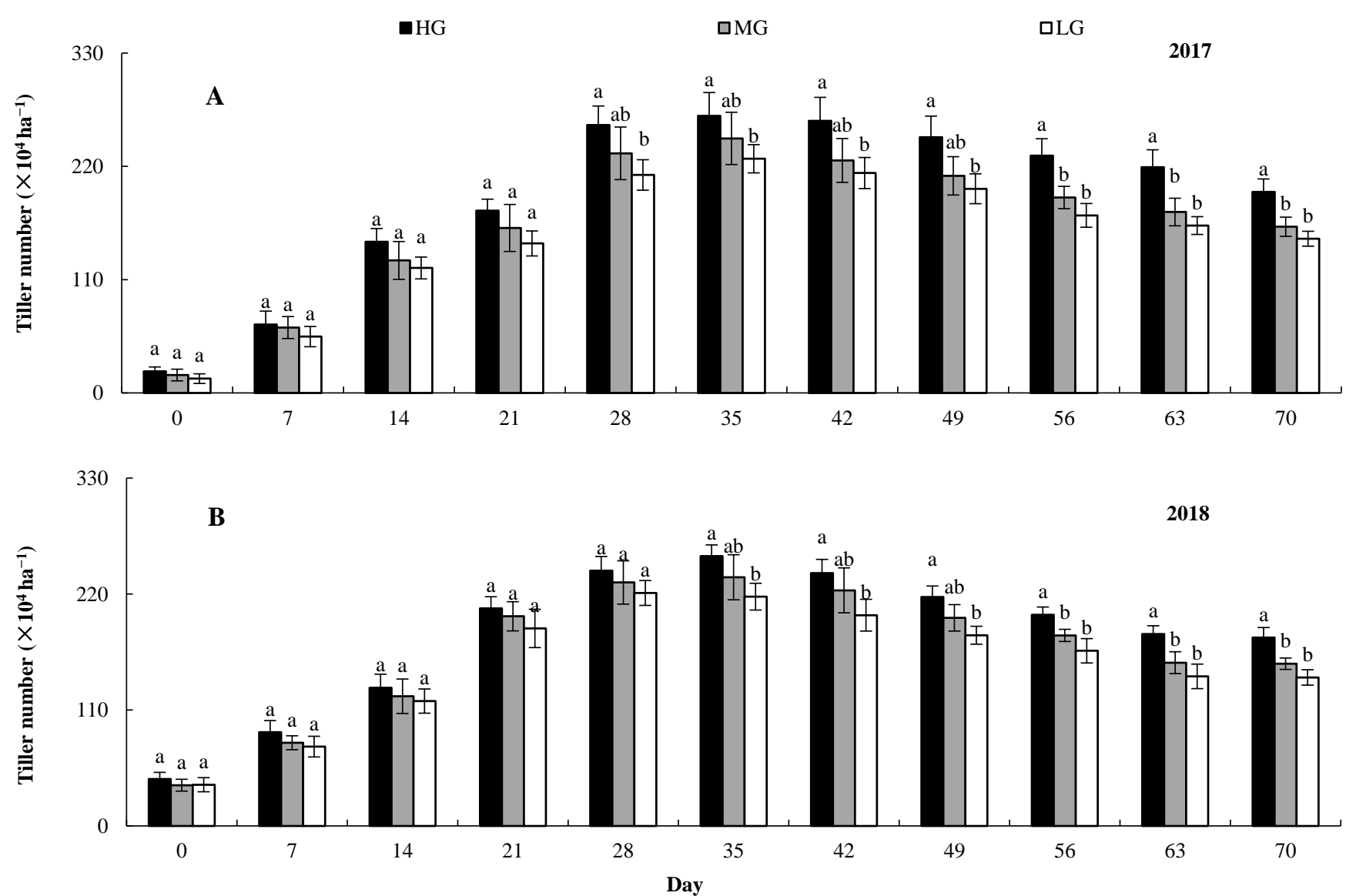

Figure 3. Tillering dynamics of different yield varieties groups in 2017 (A), and tillering dynamics of different yield varieties groups in 2018 (B). HG, MG, and LG indicate high-yield varieties group, middle-yield varieties group, and low-yield varieties group. The error bars represent the standard error of the mean and means followed by a different small letter within a column are significantly different at 0.05 probability levels respectively, as determined by LSD. 


\subsection{Analysis of Other Panicle Characteristics of Different Yield-Level Groups}

In 2017 and 2018, panicle characteristics of different yield-level groups were similar and showed the same trends (Table 5). Compared with panicle traits, the average panicle length and panicle weight per panicle of HG, MG, and LG showed an upward trend, while the primary branch, secondary branch, and grain density showed a downward trend, but these trends did not reach significant levels. The analysis also showed that the correlation between each index and yield did not reach a significant level. Statistics indicated that the panicle length of HG over two years was $27.58 \sim 28.90 \mathrm{~cm}$, the panicle weight was 5.32 5.82 g/panicle, the number of primary branches was 14.08 16.56 per panicle, the number of secondary branches was $34.64 \sim 45.32$ per panicle, and the grain density was $7.64-10.18$ per $\mathrm{cm}$.

Table 5. Differences in panicle length, primary branches, secondary branches, panicle weight, and grain density of different yield varieties groups in 2017 and 2018.

\begin{tabular}{|c|c|c|c|c|c|c|}
\hline Year & Group & $\begin{array}{l}\text { Panicle Length } \\
(\mathrm{cm})\end{array}$ & $\begin{array}{l}\text { Primary Branches } \\
\text { (number panicle }^{-1} \text { ) }\end{array}$ & $\begin{array}{l}\text { Second Branches } \\
\text { (number panicle }^{-1} \text { ) }\end{array}$ & $\begin{array}{l}\text { Panicle Weight } \\
\text { (g panicle }^{-1} \text { ) }\end{array}$ & $\begin{array}{l}\text { Grain Density } \\
\left(\text { number } \mathrm{cm}^{-1}\right)\end{array}$ \\
\hline \multicolumn{7}{|l|}{2017} \\
\hline & HG & $27.02 \pm 0.81 \mathrm{a}$ & $16.24 \pm 1.00 \mathrm{a}$ & $40.02 \pm 2.78 \mathrm{a}$ & $5.52 \pm 0.49 a$ & $9.38 \pm 0.52 \mathrm{a}$ \\
\hline & MG & $28.7 \pm 0.42 \mathrm{a}$ & $15.11 \pm 0.57 \mathrm{a}$ & $37.38 \pm 0.85 a$ & $5.88 \pm 0.31 \mathrm{a}$ & $8.82 \pm 0.25 a$ \\
\hline & LG & $29.55 \pm 0.61 \mathrm{a}$ & $15.09 \pm 0.72 \mathrm{a}$ & $36.77 \pm 1.61 \mathrm{a}$ & $6.72 \pm 0.34 \mathrm{a}$ & $8.16 \pm 0.72 \mathrm{a}$ \\
\hline \multicolumn{7}{|l|}{2018} \\
\hline & HG & $26.86 \pm 1.43 \mathrm{a}$ & $15.81 \pm 2.35 \mathrm{a}$ & $39.94 \pm 2.53 \mathrm{a}$ & $5.11 \pm 1.05 \mathrm{a}$ & $8.95 \pm 1.00 \mathrm{a}$ \\
\hline & MG & $27.96 \pm 0.68 a$ & $15.35 \pm 1.62 \mathrm{a}$ & $38.70 \pm 2.96 \mathrm{a}$ & $5.66 \pm 1.17 \mathrm{a}$ & $8.22 \pm 1.43 \mathrm{a}$ \\
\hline & LG & $28.67 \pm 1.74 \mathrm{a}$ & $14.18 \pm 1.23 \mathrm{a}$ & $36.29 \pm 1.33 a$ & $5.91 \pm 1.58 \mathrm{a}$ & $7.67 \pm 1.65 \mathrm{a}$ \\
\hline
\end{tabular}

HG, MG, and LG indicate high-yield varieties group, middle-yield varieties group, and low-yield varieties group. The error bars represent the standard error of the mean and means followed by a different small letter within a column are significantly different at 0.05 probability levels respectively, as determined by LSD.

\subsection{Analysis of Leaf Characteristics of Different Yield-Level Groups}

For 2017 and 2018, the leaf posture of each leaf position showed the same trend among the different yield-level groups (Figure 4). The leaf base angle, leaf droop angle, and leaf pillow distance of each leaf position increased with the decrease in yield for the three yield-level groups in both years, and the leaf base angle and leaf droop angle of each leaf position of HG were significantly lower than those of LG in terms of annual and biennial mean. Correlation analysis of the two-year mean showed that the leaf base angle, leaf droop angle, and leaf pillow distance of each leaf position were significantly or very significantly negatively correlated with yield. Statistics showed that the average leaf base angle of the three leaves for HG was $16.28^{\circ} \sim 17.62^{\circ}$, the average leaf droop angle was $0.82^{\circ} \sim 1.22^{\circ}$, and the average leaf pillow distance was $23.34 \sim 24.46 \mathrm{~cm}$. The trends of leaf length, leaf width, and distance of leaf edge were the same among different yield groups for both years (Figure 5). The leaf length of each leaf position of the three yield-level groups decreased with the increase in yield, while leaf width and distance of leaf edge increased with the increase in yield. The flag leaf width of HG in each year was significantly larger than that of LG, while the distance of leaf edge of each leaf position of HG in both years was significantly larger than that of LG. Over the two years, the yield was significantly or extremely significantly positively correlated with leaf width and the distance of leaf edge of each leaf position, but not with leaf length. Statistical results for the two years showed that the leaf length, leaf width, and distance of the leaf edge of the three leaves on HG were $48.76 \sim 57.67 \mathrm{~cm}, 1.77 \sim 1.91 \mathrm{~cm}$, and $1.45 \sim 1.65 \mathrm{~cm}$, respectively. 

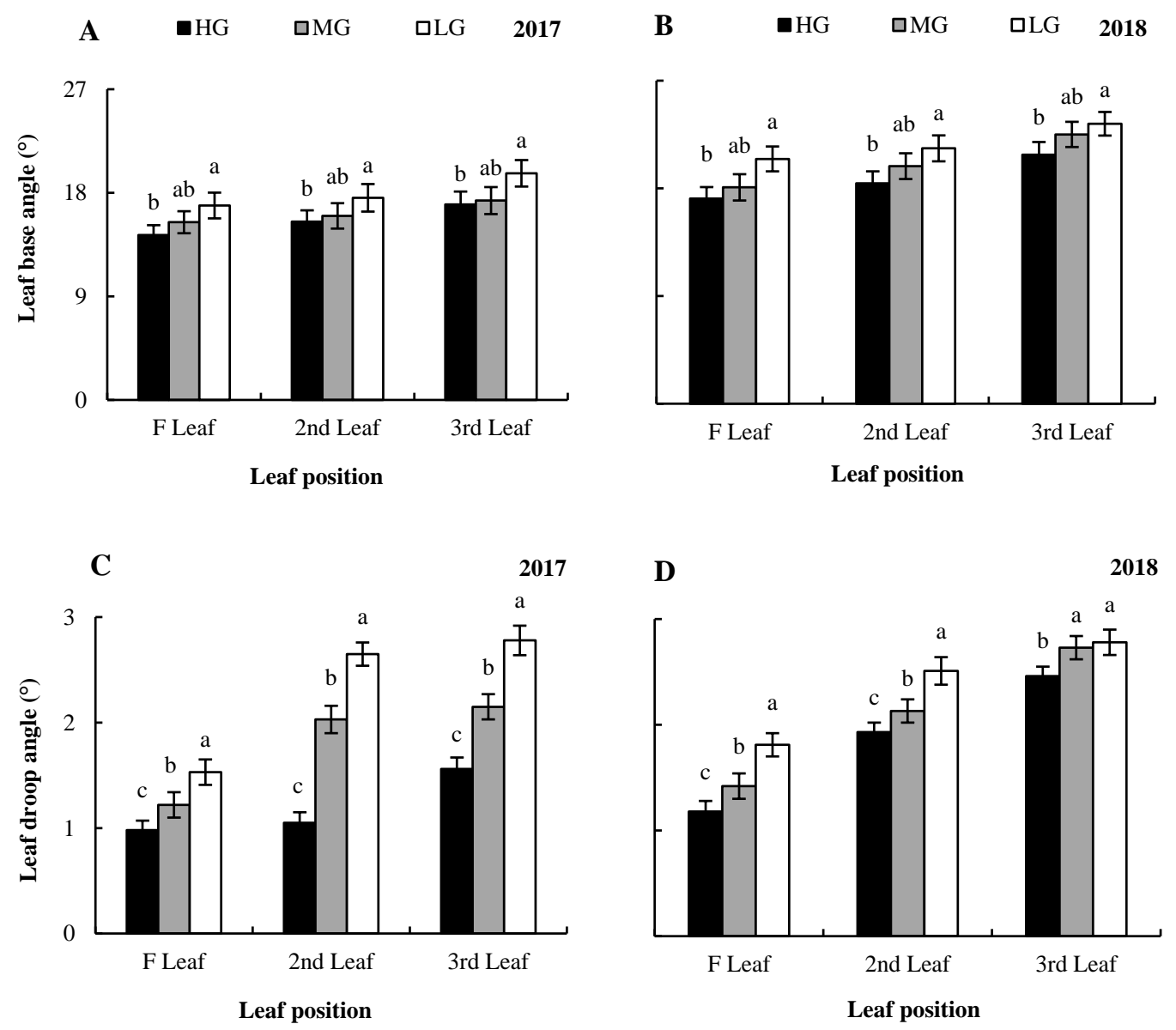

E

2017

$\mathbf{F}$

2018
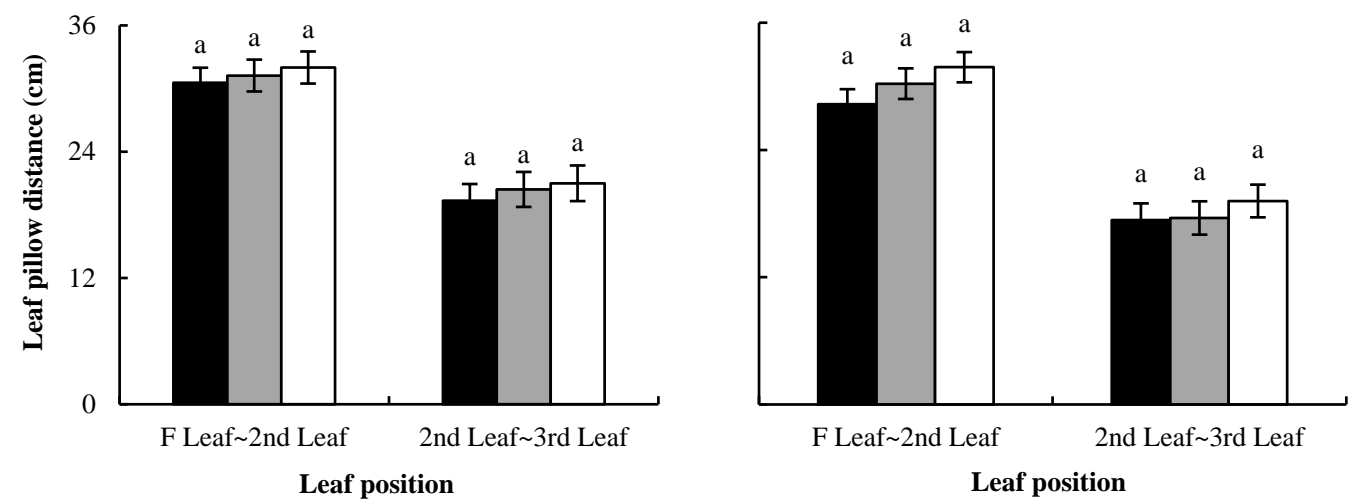

Figure 4. Differences in leaf base angle in 2017 (A), leaf base angle in 2018 (B), leaf droop angle in 2017 (C), leaf droop angle in 2018 (D), leaf pillow distance in 2017 (E) and leaf pillow distance in 2018 (F) of functional leaves of different yield varieties groups in 2017 and 2018. HG, MG, and LG indicate high-yield varieties group, middle-yield varieties group, and low-yield varieties group. F Leaf, Flag leaf; 2nd Leaf, 2nd leaf from the top; 3rd Leaf, 3rd leaf from the top. The error bars represent the standard error of the mean and means followed by a different small letter within a column are significantly different at 0.05 probability levels respectively, as determined by LSD. 

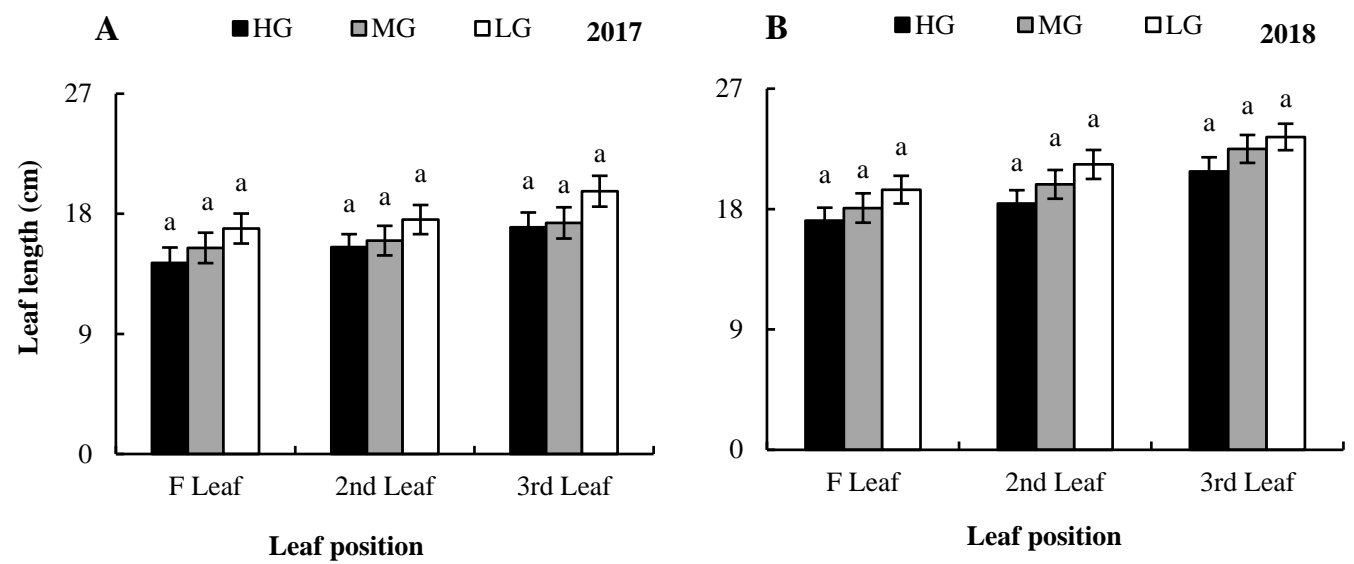

C

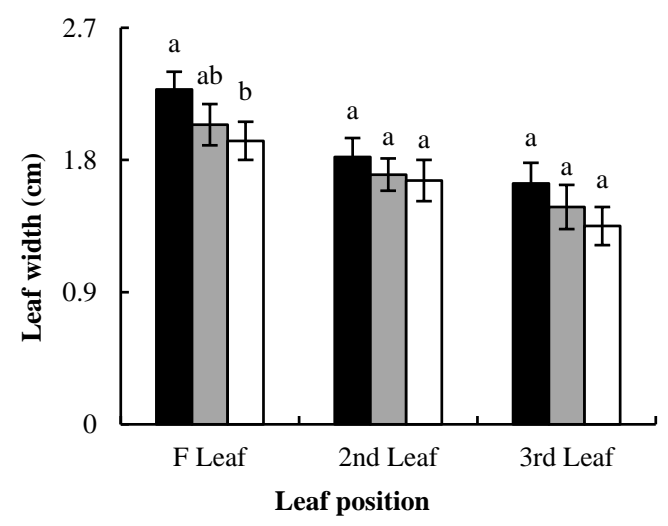

$\mathbf{E}$

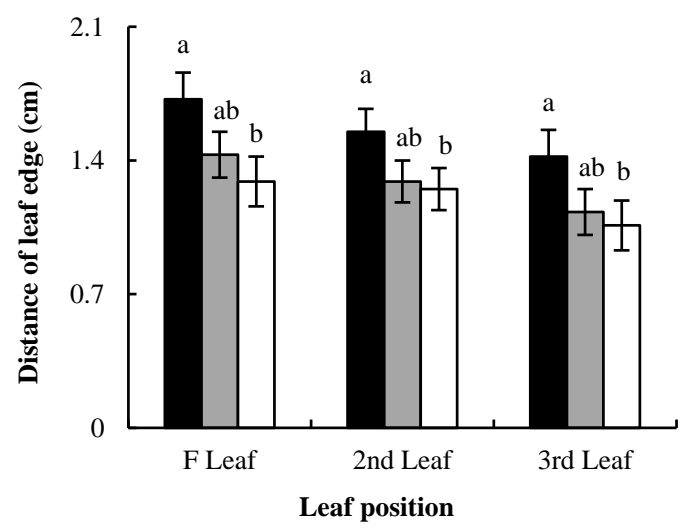

2017

D

2018

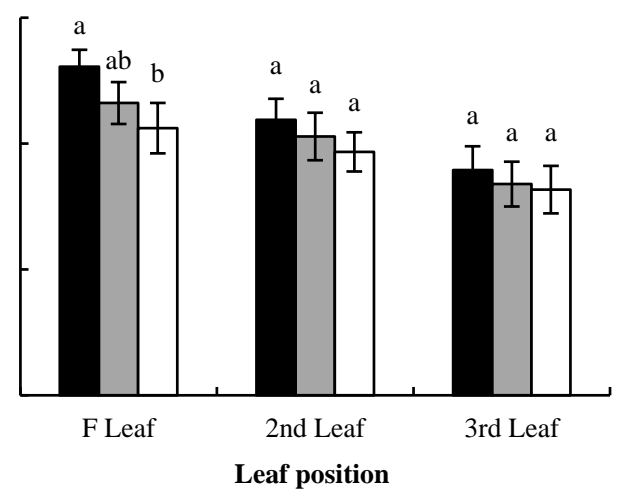

$\mathrm{F}$

2018

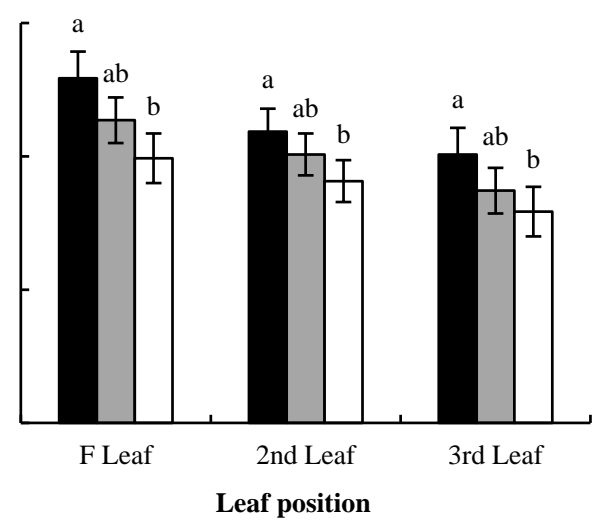

Figure 5. Differences in leaf length in 2017 (A), leaf length in 2018 (B), leaf width in 2017 (C), leaf width in 2018 (D), distance of leaf edge in 2017 (E) and distance of leaf edge in 2018 (F) of functional leaves of different yield varieties groups in 2017 and 2018. HG, MG, and LG indicate high-yield varieties group, middle-yield varieties group, and low-yield varieties group. F Leaf, Flag leaf; 2nd Leaf, 2nd leaf from the top; 3rd Leaf, 3rd leaf from the top. The error bars represent the standard error of the mean and means followed by a different small letter within a column are significantly different at 0.05 probability levels respectively, as determined by LSD.

The leaf area of each leaf position increased with the increase in yield in the three yield-level groups for both years, and the difference of leaf area of each leaf position between HG and LG reached a significant level. The leaf length to width ratio of each leaf position showed a downward trend with the increase in yield in all yield groups, and the difference between HG and LG reached a significant 
level for the 3rd leaf in 2017. The leaf roll index of each position showed a downward trend with the increase in yield in three yield-level groups for both years, and the leaf roll index of each leaf position of HG in both years was significantly lower than that of LG (Figure 6). Leaf area at each leaf position was significantly positively correlated with yield, and the leaf roll index at each leaf position was significantly negatively correlated with yield in both years, while the leaf length to width ratio was significantly or extremely significantly negatively correlated with the yield at each leaf position.
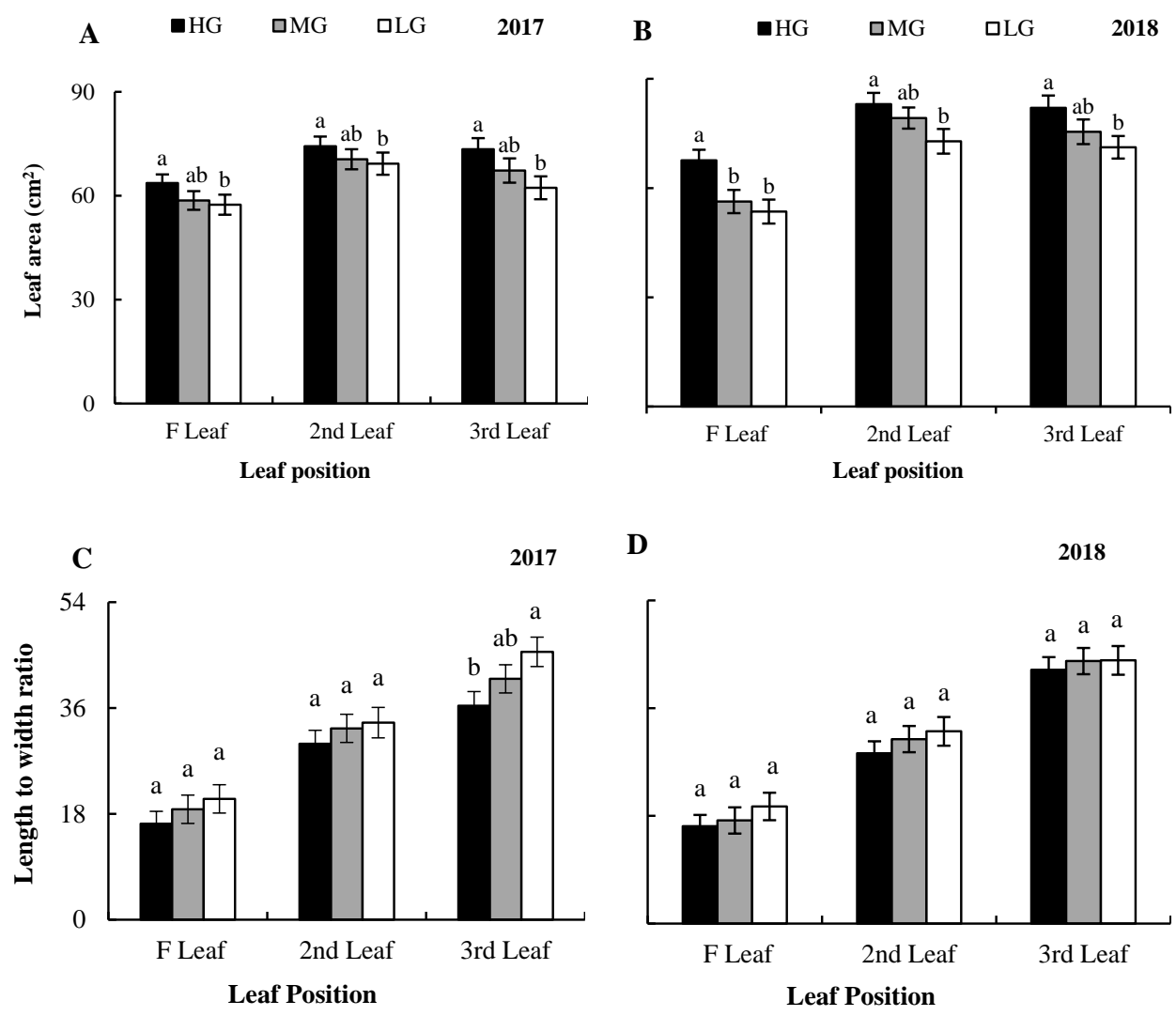

D

2018
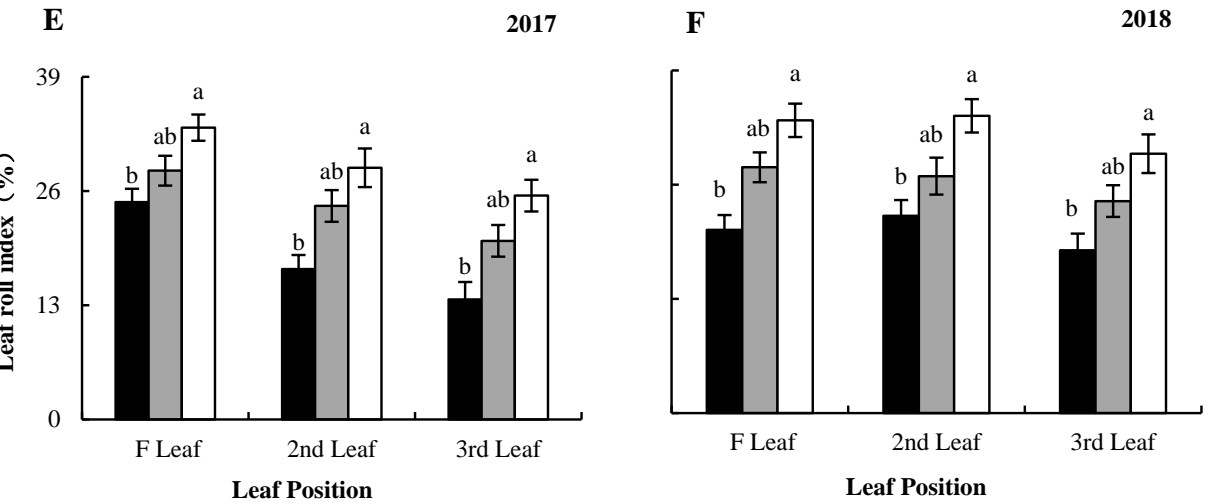

Figure 6. Differences in leaf area in 2017 (A), leaf area in 2018 (B), length to width ratio in 2017 (C), length to width in 2018 (D), leaf roll index in 2017 (E) and leaf roll index in 2018 (F) of functional leaves of different yield varieties groups in 2017 and 2018. HG, MG, and LG indicate high-yield varieties group, middle-yield varieties group, and low-yield varieties group. F Leaf, Flag leaf; 2nd Leaf, 2nd leaf from the top; 3rd Leaf, 3rd leaf from the top. The error bars represent the standard error of the mean and means followed by a different small letter within a column are significantly different at 0.05 probability levels respectively, as determined by LSD. 


\subsection{Analysis of Stem Characteristics of Different Yield-Level Groups}

For 2017 and 2018, the first internode length from the top and the plant height decreased with the increase in yield in all three groups, while the second $\sim$ fourth internode length from the top increased with the increase in yield. The trend of the internode width of the different groups was not consistent for the two years. In both years, the width of the second $\sim$ fourth internode from the top of HG was the widest among all groups, and the internode width of HG was significantly higher than that of HG and LG in the third internode from the top in 2017. The average internode length of HG was $22.81 \sim 24.29 \mathrm{~cm}$, and the average internode width was $0.54 \sim 0.60 \mathrm{~cm}$, which was slightly higher than MG and LG. The average plant height of HG was $127.30 \sim 131.56 \mathrm{~cm}$, which was lower than MG and LG, but the difference was not significant (Table 6).

\subsection{Main Plant Type Characteristics of Hybrid Mid-Season Rice and Their Relationships with Yield per Plant}

The correlation analysis showed that the yield was significantly or extremely significantly positively correlated with leaf width and leaf area, and extremely significantly negatively correlated with leaf length to width ratio. The yield showed an extremely significant positive correlation with the distance of leaf edge, and a significantly negative correlation with leaf roll index. Leaf base angle, leaf droop angle, and leaf pillow distance all showed an extremely significant negative correlation with yield and keeping the leaf compact and upright also had a positive effect on yield. Among them, the correlation between leaf droop angle and the yield was extremely significant and the absolute value of the correlation coefficient was the largest (Table 7). 
Table 6. Differences in internode length, internode width, and plant height of different yield varieties groups in 2017 and 2018.

\begin{tabular}{|c|c|c|c|c|c|c|c|c|c|c|}
\hline \multirow[b]{2}{*}{ Year } & \multirow[b]{2}{*}{ Group } & \multicolumn{4}{|c|}{ Internode Length (cm) } & \multicolumn{4}{|c|}{ Internode Width $(\mathrm{cm})$} & \multirow{2}{*}{$\begin{array}{c}\text { Plant Height } \\
\text { (cm) }\end{array}$} \\
\hline & & $\begin{array}{l}\text { 1st Internode } \\
(\mathrm{cm})\end{array}$ & $\begin{array}{l}\text { 2nd Internode } \\
(\mathrm{cm})\end{array}$ & $\begin{array}{l}\text { 3rd Internode } \\
(\mathrm{cm})\end{array}$ & $\begin{array}{l}\text { 4th Internode } \\
\text { (cm) }\end{array}$ & $\begin{array}{l}\text { 1st Internode } \\
(\mathrm{cm})\end{array}$ & $\begin{array}{l}\text { 2nd Internode } \\
\text { (cm) }\end{array}$ & $\begin{array}{l}\text { 3rd Internode } \\
(\mathrm{cm})\end{array}$ & $\begin{array}{l}\text { 4th Internode } \\
(\mathrm{cm})\end{array}$ & \\
\hline \multicolumn{11}{|l|}{2017} \\
\hline & HG & $40.22 \pm 1.65 \mathrm{a}$ & $23.10 \pm 1.57 \mathrm{a}$ & $18.89 \pm 2.21 \mathrm{a}$ & $12.56 \pm 1.32 \mathrm{a}$ & $0.31 \pm 0.01 \mathrm{a}$ & $0.53 \pm 0.02 \mathrm{a}$ & $0.67 \pm 0.01 \mathrm{a}$ & $0.76 \pm 0.03 a$ & $127.69 \pm 2.35 \mathrm{a}$ \\
\hline & MG & $41.99 \pm 2.12 \mathrm{a}$ & $22.37 \pm 1.56 \mathrm{a}$ & $17.56 \pm 2.45 \mathrm{a}$ & $11.33 \pm 1.36 \mathrm{a}$ & $0.32 \pm 0.02 \mathrm{a}$ & $0.50 \pm 0.02 \mathrm{a}$ & $0.63 \pm 0.03 b$ & $0.72 \pm 0.04 \mathrm{a}$ & $129.35 \pm 2.68 \mathrm{a}$ \\
\hline & LG & $42.05 \pm 2.44 \mathrm{a}$ & $20.95 \pm 2.13 \mathrm{a}$ & $17.12 \pm 1.66 \mathrm{a}$ & $10.30 \pm 1.55 \mathrm{a}$ & $0.30 \pm 0.04 \mathrm{a}$ & $0.49 \pm 0.04 \mathrm{a}$ & $0.64 \pm 0.02 \mathrm{~b}$ & $0.73 \pm 0.05 \mathrm{a}$ & $134.55 \pm 2.55 \mathrm{a}$ \\
\hline \multicolumn{11}{|l|}{2018} \\
\hline & HG & $41.34 \pm 1.99 \mathrm{a}$ & $22.25 \pm 1.89 \mathrm{a}$ & $17.76 \pm 1.14 \mathrm{a}$ & $11.95 \pm 1.49 \mathrm{a}$ & $0.33 \pm 0.02 \mathrm{a}$ & $0.53 \pm 0.03 a$ & $0.65 \pm 0.04 \mathrm{a}$ & $0.76 \pm 0.03 a$ & $131.17 \pm 2.59 \mathrm{a}$ \\
\hline & MG & $43.53 \pm 2.21 \mathrm{a}$ & $21.41 \pm 2.45 \mathrm{a}$ & $17.40 \pm 1.56 \mathrm{a}$ & $11.14 \pm 1.67 \mathrm{a}$ & $0.32 \pm 0.03 \mathrm{a}$ & $0.51 \pm 0.02 \mathrm{a}$ & $0.63 \pm 0.05 \mathrm{a}$ & $0.74 \pm 0.04 \mathrm{a}$ & $132.71 \pm 2.47 \mathrm{a}$ \\
\hline & LG & $44.09 \pm 2.25 \mathrm{a}$ & $21.11 \pm 3.11 \mathrm{a}$ & $16.32 \pm 1.55 \mathrm{a}$ & $10.72 \pm 2.42 \mathrm{a}$ & $0.31 \pm 0.02 \mathrm{a}$ & $0.53 \pm 0.01 \mathrm{a}$ & $0.60 \pm 0.03 \mathrm{a}$ & $0.71 \pm 0.06 \mathrm{a}$ & $133.91 \pm 3.22 \mathrm{a}$ \\
\hline
\end{tabular}

internode from the top; 3rd internode, third internode from the top; 4th internode, fourth internode from the top. The error bars represent the standard error of the mean and means followed by a different small letter within a column are significantly different at 0.05 probability levels respectively, as determined by LSD.

Table 7. Correlation analysis of main plant type index and yield per plant from 2017 to 2018.

\begin{tabular}{|c|c|c|c|c|c|c|c|c|}
\hline Index & $\begin{array}{l}\text { Average Leaf } \\
\text { Width }\end{array}$ & $\begin{array}{l}\text { Average Leaf } \\
\text { Roll Index }\end{array}$ & $\begin{array}{c}\text { Average Leaf } \\
\text { Area }\end{array}$ & $\begin{array}{l}\text { Average Leaf } \\
\text { Length to } \\
\text { Width Ratio }\end{array}$ & $\begin{array}{c}\text { Average } \\
\text { Distance of } \\
\text { Leaf Edge }\end{array}$ & $\begin{array}{c}\text { Average Leaf } \\
\text { Base Angle }\end{array}$ & $\begin{array}{c}\text { Average Leaf } \\
\text { Droopy Angle }\end{array}$ & $\begin{array}{c}\text { Average Leaf } \\
\text { Pillow Distance }\end{array}$ \\
\hline Average leaf base angle & $-0.463 *$ & $0.487 *$ & -0.217 & 0.766 ** & $-0.538 *$ & & & \\
\hline Average leaf droopy angle & -0.397 & $0.469 *$ & -0.207 & $0.619 * *$ & -0.486 * & $0.805^{* *}$ & & \\
\hline Internode width & $0.623 * *$ & -0.203 & $0.709 * *$ & -0.135 & $0.531 *$ & -0.051 & -0.114 & -0.129 \\
\hline Plant height & 0.187 & 0.113 & 0.395 & 0.379 & 0.066 & $0.510 *$ & $0.558 *$ & $0.455 *$ \\
\hline Seed-setting ratio & 0.289 & $-0.623 * *$ & 0.264 & -0.25 & $0.483 *$ & -0.523 * & $-0.478 *$ & -0.228 \\
\hline Panicle-setting rate & $0.561 *$ & -0.518 * & 0.422 & $-0.574 * *$ & $0.629 * *$ & -0.42 & -0.493 * & -0.419 \\
\hline Effective panicles number & $0.453 *$ & -0.325 & 0.269 & $-0.621 * *$ & $0.462 *$ & $-0.651 * *$ & -0.474 * & -0.357 \\
\hline Yield & 0.700 ** & $-0.526 *$ & $0.500 *$ & $-0.767 * *$ & 0.723 ** & $-0.760 * *$ & $-0.833 * *$ & $-0.610 * *$ \\
\hline
\end{tabular}

${ }^{*}$ and ${ }^{* *}$, significant differences at the 0.05 and 0.01 probability levels, respectively. 


\section{Discussion}

The yield per unit area of rice is determined by the number of effective panicles per unit area, the number of spikelets per panicle, seed setting rate, and 1000-grain weight. These results, obtained from a two-year experiment, indicate that the total growth period was similar for all the varieties, but that the yield per unit area varied significantly. According to the clustering of values of yield per unit area, all the rice varieties tested can be classified into three groups: HG, MG, and LG, with the average yield of HG being significantly higher than those of MG and LG. Analysis of the components of yield showed that the number of effective panicles per unit area for HG was significantly higher than that of MG and LG, and this was the main reason for the difference in yield among different groups, which was consistent with the results of Ma et al. [16]. In this experiment, the tiller increase rate of HG was higher and faster, and the period was longer during early growth. The decline in the tiller number was lower in the later stage. The higher maximum tiller number and higher panicle-setting rate ensured that there were more effective panicles. In addition, the seed-setting rate and the number of filled grains per panicle of HG were higher than those of MG and LG, and more filled grains guaranteed a higher yield, which agreed with Sheehy et al. [17]. However, with the increasing yield, the 1000-grain weight showed a decreasing trend; meanwhile, we also observed that most internodes of HG were longer and wider, which meant that internodes of HG had accumulated more biomass yield. One reason for the low 1000-grain weight of HG may be that the biomass yield accumulating in the stem did not sufficiently transfer to grains [18]. In panicle characters, the grain weight per panicle of HG was lower than those of MG and LG, and HG depended on more effective panicles to achieve high yield, which was inconsistent with the results of Pasuquin et al. [19]. Panicle length in HG was shorter with more primary and secondary branches and more grains, and its yield of a single stem was guaranteed by its higher grain density. Therefore, we believe that the desired panicle traits of high-yield mid-season hybrid rice should be achieved by maintaining a longer panicle length, a larger grain weight, and a larger grain weight per panicle, with more effective panicles per unit area, higher seed-setting rate, more grains per panicle, more primary and secondary branches, and a denser grain. For breeding, high-yield mid-season indica hybrid rice varieties can be cultivated through the coordination of panicles and grains, using multi-stem and multi-panicle approaches. The appropriate leaf morphology of crops is an important condition for high yield [20]. Under the premise of large storage capacity, a good light-receiving posture can maintain high photosynthetic performance in a population, promoting a high yield [21]. In this study, the leaf base angle, leaf droop angle, and leaf pillow distance of the upper three leaves of HG were lower than those of MG and LG, implying that the leaves of HG were more upright and compact, which accords with the ideal leaf posture described previously [22]. The results also show that the yield was negatively correlated with leaf base angle, leaf droop angle, and leaf pillow distance of the upper three leaves, which further indicates that the vertical and compact leaf shape was the reason for the yield of HG in this experiment. In terms of leaf shape, the leaf length of the upper three leaves in the high-yield group is shorter than that in MG and LG, but the leaf is wider, with a smaller leaf length to width ratio and a larger leaf area. Leaf area and leaf width were significantly positively correlated with yield, and a larger leaf area ensures a higher photosynthetic capacity [23]. Therefore, the high-yield group has a material basis for its high yield in its leaf shape. The leaf length to width ratio was negatively correlated with yield and positively correlated with leaf base angle and leaf droop angle, which indicates that slender leaves droop more easily, and this is more likely to result in low yields due to poor basal light receptivity [22]. Moderate curl in rice leaves can keep the leaves upright but excessive leaf curl will affect photosynthetic efficiency [24,25]. These results show that the leaf roll index of MG and LG was higher than that of HG, and showed a significant negative correlation with yield, while the distance of the leaf edge had an extremely significant positive correlation with yield, suggesting that the leaf roll index exceeding the ideal range was one of the reasons which limited the increased yield of MG and LG. Therefore, we believe that the leaf morphology of the high-yielding hybrid rice should have the characteristics of a smaller leaf base angle, a smaller leaf droop angle, a smaller leaf pillow distance, a wider leaf width, 
a moderate leaf length, and a moderate distance of the leaf edge of the upper three leaves, in order to maintain an upright and compact nature, a moderate curl, larger leaf area, and an appropriate length to width ratio of the upper three leaves. It also shows that in future rice breeding for high yield, attention should be paid to increasing the leaf width, reducing the leaf length, and maintaining an appropriate distance of the leaf edge, in order to improve the light-receiving posture and surface area of rice plants to achieve high yield.

The rice stem is an important element in plant growth and development, and its consideration is the basis of improving the canopy structure for better photosynthetic productivity [26]. The ideal stem in rice is short and thick in the first $\sim$ third internodes above the base, which then supports the growth of the whole plant. Longer and tougher internodes below the panicle can reduce the phenomenon of lodging-induced yield reduction [27]. The ideal plant height should be higher, allowing more solar energy to be intercepted, and the utilization rate of solar energy to be improved to achieve high yield, especially in areas where light may be insufficient [28]. In this experiment, the plants in all the tested varieties did not lodge, and the width of the internodes of HG was wider than those of MG and LG. The wider internodes always mean that the stems have more vascular bundles, which could promote the transport of leaf photosynthates to the panicles and ensure the smooth transport pathway of photosynthates [18]. However, the 1000-grain weight of HG is lower than MG and LG, which indicates that there are other factors that lead to poor transportation of photosynthetic products in the stem with more vascular bundles, but it is still unclear. The internodes under the panicles of HG were shorter than those of MG and LG, the internodes above the base were longer, the length distribution between the internodes was more balanced, and the plant height was less than those of MG and LG. These findings were different from those of previous studies, which indicate that those newly bred mid-season indica hybrid rice varieties are unique, and the requirement for the length characteristics of the internodes of high-yield hybrid rice is different from that of previous varieties. Further study of the genetic physiology of the stem of those high-yield rice varieties is necessary. Correlation analysis showed that the length of the internode under the panicle was negatively correlated with the yield, and the length of the first third internode above base was positively correlated with the yield. Therefore, based on the above research results, we suggested that the stem morphology of high-yield hybrid rice bred in the future should have the characteristics of stronger and thicker internodes, slightly longer first $\sim$ third internodes above the base, a more uniform internode length, and slightly shorter internodes under the panicle.

\section{Conclusions}

In these experiments, the yields of HG, MG, and LG were significantly different. The direct reason for these differences was the differences in numbers of effective panicles. From the plant type characteristics, the leaf type factors were the most important reason causing yield difference of HG, MG, and LG, and the leaf droop angle was the most important factor affecting yield in leaf type factors.

These results can help breeders select high-yield mid-season indica hybrid rice varieties in the future. The high-yield plant-type model of indica hybrid rice is proposed here, with an average leaf base angle of functional leaves of $16.28^{\circ} \sim 17.62^{\circ}$, an average leaf droop angle of $0.82^{\circ} \sim 1.22^{\circ}$, an average leaf pillow distance of $23.34 \sim 24.46 \mathrm{~cm}$, an average leaf length of $48.76 \sim 57.67 \mathrm{~cm}$, an average leaf width of 1.77 1.91 cm, an average distance to the leaf edge $1.45 \sim 1.65 \mathrm{~cm}$, average internode length $22.81 \sim 24.29 \mathrm{~cm}$, average internode width $0.54 \sim 0.6 \mathrm{~cm}$, plant height $127.30 \sim 131.56 \mathrm{~cm}, 1000$-grain weight 26.48 27.84 g, panicle length $27.58 \sim 28.90 \mathrm{~cm}$, primary branch $14.08 \sim 16.56$ per panicle, secondary branch 34.64 45.32 per panicle, filled grain number 186.60 234.08 per panicle, and effective panicle number $161.20 \times 10^{4} \sim 186.46 \times 10^{4} \mathrm{hm}^{-2}$, resulting in a yield of $49.55 \sim 50.79 \mathrm{~g}$ per plant.

Author Contributions: Conceptualization, G.H. and C.Z.; methodology, C.Z.; investigation, X.Z., B.Z., M.H., L.C. and H.Y.; resources, C.Z.; data curation, X.Z.; writing-original draft preparation, X.Z.; writing-review and editing, H.A.H. and S.H.; project administration, G.H.; funding acquisition, G.H. and C.Z. All authors have read and agreed to the published version of the manuscript. 
Funding: This research was supported by the National Key Research and Development Program "Seven Crop Breeding" key project (2017YFD0100201) and the Chongqing Technology Innovation and Application Demonstration Project (cstc2018jscx-msybX0250).

Acknowledgments: The authors are very grateful for the help provided by Zi Shujun, Zhu Dongming, Lai Weiqiang, Hua Xiurui, Feng Yongsen, Wang Jiawei, Li Lianguo, and Yan Meng in data investigation of this experiment, Yang Zhenglin and Yao Hesheng in experimental guidance, and Xu Fuxian in writing guidance.

Conflicts of Interest: The authors declare no conflict of interest.

\section{References}

1. Mae, T.; Inaba, A.; Kaneta, Y.; Masaki, S.; Sasaki, M.; Aizawa, M.; Okawa, S.; Hasegawa, S.; Makino, A. A large-grain rice cultivar, Akita 63, exhibits high yields with high physiological N-use efficiency. Field Crops Res. 2006, 97, 227-237. [CrossRef]

2. Amanullah, I.; Inamullah, X. Dry matter partitioning and harvest index differ in rice genotypes with variable rates of phosphorus and zinc nutrition. Rice Sci. 2016, 23, 78-87. [CrossRef]

3. Hirose, T. Development of the monsi-saeki theory on canopy structure and function. Ann. Bot. 2005, 95, 483-494. [CrossRef] [PubMed]

4. Yang, X.; Lin, R.K.; Zhang, W.Y.; Xu, Y.K.; Wei, X.; Zhou, C.; Qin, J.H.; Li, H.S. Comparison of Cd subcellular distribution and $\mathrm{Cd}$ detoxification between low/high $\mathrm{Cd}$-accumulative rice cultivars and sea rice. Ecotoxicol. Environ. Saf. 2019, 185, 109698. [CrossRef]

5. Kato, T.; Taniguchi, A.; Horibata, A. Effects of the alleles at and on the grain filling in extra-heavy panicle type of rice. Crop Sci. 2010, 50, 2448-2456. [CrossRef]

6. Murchie, E.; Hubbart, S.; Peng, S.; Horton, P. Acclimation of photosynthesis to high irradiance in rice: Gene expression and interactions with leaf development. J. Exp. Bot. 2005, 56, 449-460. [CrossRef]

7. Mulsanti, I.; Yamamoto, T.; Ueda, T.; Samadi, A.; Kamahora, E.; Rumanti, I.; Thanh, V.; Adachi, S.; Suzuki, S.; Kanekatsu, M.; et al. Finding the superior allele of japonica-type for increasing stem lodging resistance in indica rice varieties using chromosome segment substitution line. Rice 2018, 11, 25. [CrossRef]

8. Yan, C.; Yan, S.; Yang, Y.; Zeng, X.; Fang, Y.; Zeng, S.; Tian, C.; Sun, Y.; Tang, S.; Gu, M. Development of gene-tagged markers for quantitative trait loci underlying rice yield components. Euphytica 2009, 169, 215-226. [CrossRef]

9. Yoshida, H.; Horie, T.; Shiraiwa, T. A model explaining genotypic and environmental variation of rice spikelet number per unit area measured by cross-locational experiments in Asia. Field Crops Res. 2006, 97, 337-343. [CrossRef]

10. Yang, Z.Y.; Li, N.; Ma, J.; Sun, Y.J.; Xu, H. High-yielding traits of heavy panicle varieties under triangle planting geometry: A new plant spatial configuration for hybrid rice in China. Field Crops Res. 2014, 168, 135-147. [CrossRef]

11. Donald, C. The breeding of crop ideotypes. Euphytica 1968, 17, 385-403. [CrossRef]

12. Ma, J.; Ma, W.B.; Ming, D.F.; Yang, S.M.; Zhu, Q.S. Characteristics of rice plant with heavy panicle. J. Integr. Agric. 2006, 5, 911-918. [CrossRef]

13. Jin, F.; Wang, H.; Xu, H.; Liu, T.; Tang, L.; Wang, X.; Jiang, Y.; Yang, L.; Li, M.; Sui, M.; et al. Comparisons of plant-type characteristics and yield components in filial generations of Indica $\times$ Japonica crosses grown in different regions in China. Field Crops Res. 2013, 154, 110-118. [CrossRef]

14. Zhang, J.; Li, G.; Song, Y.; Liu, Z.; Yang, C.; Tang, S.; Zheng, C.; Wang, S.; Ding, Y. Lodging resistance characteristics of high-yielding rice populations. Field Crops Res. 2014, 161, 64-74. [CrossRef]

15. Hu, N.; Lu, C.; Yao, K.; Zou, J. Simulation on distribution of photosynthetically active radiation in canopy and optimum leaf rolling index in rice with rolling leaves. Rice Sci. 2009, 16, 217-225. [CrossRef]

16. Ma, J.; Tao, S.S. Study on the Practice and High-yielding Mechanism of Super-sparse-cultivation Associated with Maximum-tiller Seedling of Hybrid Rice. J. Integr. Agric. 2010, 3, $298-306$.

17. Sheehy, J.; Dionora, M.; Mitchell, P. Spikelet numbers, sink size and potential yield in rice. Field Crops Res. 2001, 71,77-85. [CrossRef]

18. Meng, T.Y.; Wei, H.H.; Li, C.; Dai, Q.G.; Xu, K.; Huo, Z.Y.; Wei, H.Y.; Guo, B.W.; Zhang, H.C. Morphological and physiological traits of large-panicle rice varieties with high filled-grain percentage. J. Integr. Agric. 2015, 15, 1751-1762. [CrossRef] 
19. Pasuquin, E.; Lafarge, T.; Tubana, B. Transplanting young seedlings in irrigated rice fields: Early and high tiller production enhanced grain yield. Field Crops Res. 2008, 105, 141-155. [CrossRef]

20. Liu, X.; Li, Y. Varietal difference in the correlation between leaf nitrogen content and photosynthesis in rice (Oryza sativa L.) plants is related to specific leaf weight. J. Integr. Agric. 2016, 15, 2002-2011. [CrossRef]

21. Horie, T.; Shiraiwa, T.; Homma, K.; Katsura, K.; Maeda, S.; Yoshida, H. Can yields of lowland rice resume the increases that they showed in the 1980s? Plant Prod. Sci. 2005, 8, 259-274. [CrossRef]

22. Li, G.; Xue, L.; Gu, W.; Yang, C.; Wang, S.; Ling, Q.; Qin, X.; Ding, Y. Comparison of yield components and plant type characteristics of high-yield rice between taoyuan, a 'special eco-site' and nanjing, China. Field Crops Res. 2009, 112, 214-221. [CrossRef]

23. Vaesen, K.; Gilliams, S.; Nackaerts, K.; Coppin, P. Ground-measured spectral signatures as indicators of ground cover and leaf area index: The case of paddy rice. Field Crops Res. 2001, 69, 13-25. [CrossRef]

24. Fang, L.; Zhao, F.; Cong, Y.; Sang, X.; Du, Q.; Wang, D.; Li, Y.; Ling, Y.; Yang, Z.; He, G. Rolling-leaf14 is a 2OG-Fe (II) oxygenase family protein that modulates rice leaf rolling by affecting secondary cell wall formation in leaves. Plant Biotechnol. J. 2012, 10, 524-532. [CrossRef] [PubMed]

25. Chang, T.G.; Zhao, H.L.; Wang, N.; Song, Q.F.; Xiao, Y.; Qu, M.N.; Zhu, X.G. A three-dimensional canopy photosynthesis model in rice with a complete description of the canopy architecture, leaf physiology, and mechanical properties. J. Exp. Bot. 2019, 70, 2479-2490. [CrossRef] [PubMed]

26. Wu, W.; Huang, J.L.; Cui, K.H.; Nie, L.X.; Wang, Q.; Yang, F.; Shah, F.; Yao, F.X.; Peng, S.B. Sheath blight reduces stem breaking resistance and increases lodging susceptibility of rice plants. Field Crops Res. 2012, 128, 101-108. [CrossRef]

27. Huang, G.X.; Ding, C.F.; Guo, F.Y.; Li, X.G.; Zhou, Z.G.; Zhang, T.L.; Wang, X.X. The Role of Node Restriction on Cadmium Accumulation in the Brown Rice of 12 Chinese Rice (Oryza sativa L.) Cultivars. J. Agric. Food Chem. 2017, 65, 10157-10164. [CrossRef]

28. Wei, X.; Xu, J.; Guo, H.; Jiang, L.; Chen, S.; Yu, C.; Zhou, Z.; Hu, P.; Zhai, H.; Wan, J. Dth8 suppresses flowering in rice, influencing plant height and yield potential simultaneously. Plant Physiol. 2010, 153, 1747-1758. [CrossRef]

Publisher's Note: MDPI stays neutral with regard to jurisdictional claims in published maps and institutional affiliations.

(C) 2020 by the authors. Licensee MDPI, Basel, Switzerland. This article is an open access article distributed under the terms and conditions of the Creative Commons Attribution (CC BY) license (http://creativecommons.org/licenses/by/4.0/). 